\title{
Augalų biomasėje sukaupto anglies kiekio ịvertinimas skirtingais būdais renatūralizuojamose ariamose žemėse
}

\author{
Asta Kazlauskaitė-Jadzevičè ${ }^{1}$, \\ Saulius Marcinkonis ${ }^{2}$ \\ ${ }^{1}$ Lietuvos agrariniu ir mišku \\ mokslu centras, \\ Instituto al. 1, \\ LT-58344 Akademija, Kèdainiu r. \\ El.paštasasta.kaz@gmail.com \\ ${ }^{2}$ Vilniaus kolegija, \\ Saltoniškių g. 58, \\ LT-08105 Vilnius \\ El.paštass.marcinkonis@viko.lt
}

Lietuvos agrarinių ir miškų mokslų centro (LAMMC) Vokès filiale nuo 1995 m. vykdomi lauko aikštelių tyrimai, kurių tikslas yra nustatyti skirtingų renatūralizacijos būdų ịtaką anglies akumuliacijai fitocenozių produkuojamoje biomasèje priesmèlio - paprastojo išplautžemio (Haplic Luvisol) dirvožemyje. Apibendrinus 20 metų tyrimų rezultatus nustatyta, kad didžiausias vidutinis anglies kiekis sukauptas apželdintos mišku aikštelès biomasėje (5,59 $\mathrm{t} \mathrm{ha}^{-1}$ per metus), kur auga paprastosios pušys (Pinus Sylvestris), o mažiausias - dirvono fitocenozėje $\left(0,85 \mathrm{t} \mathrm{ha}^{-1}\right.$ per metus). Tradicinès lauko sèjomainos augalų biomasëje vidutinis anglies kiekis (1,98 $\mathrm{t} \mathrm{ha}^{-1}$ per metus) buvo kiek didesnis nei netrę̌̌iamos šienaujamos pievos fitocenozeje $\left(1,85 \mathrm{t}\right.$ ha ${ }^{-1}$ per metus). Tręšimas mineralinèmis NPK trąšomis esmingai (1,57-1,74 karto) didino sukauptą anglies kiekị lauko sèjomainos ir pievos fitocenozėse. Tręšto sèjomainos lauko antžeminèje augalų biomasëje sukauptos anglies kiekis varijavo priklausomai nuo augalų rūšies (nuo 0,07 iki $3,24 \mathrm{t} \mathrm{ha}^{-1}$ per metus). Nustatyta, kad augalu vegetacijos metu permainingos meteorologinès sąlygos daro silpną arba vidutinio stiprumo ịtaką sèjomainos lauko fitocenozių derliui, taip pat ir antžeminès anglies kaupimui fitocenozių produkuotoje biomasèje. Netręšiamose lauko sèjomainos fitocenozėse sukaupiamo anglies kiekio koreliacinis ryšys su oro temperatūra buvo silpnas ir neigiamas $(r=-0,4)$, su kritulių kiekiu - teigiamas, bet taip pat silpnas $(r=0,4)$. Nustatytas atvirkštinis vidutinio stiprumo ryšys $(r=-0,6)$ tarp tręšiamų sejjomainos lauko fitocenozių antžeminès anglies ir augalų vegetacijos laikotarpio vidutinès temperatūros, t. y. aukštesnès temperatūros mažino potencialiai fitocenozėje galimą sukaupti antžeminị anglies kiekị.

Raktažodžiai: biomasès anglis, ariamų žemių renatūralizacija, paprastasis išplautžemis (Haplic Luvisol)

\section{IVADAS}

Pietryčių Lietuvoje yra nemažai nederlingų dirvožemių ir jų racionalaus panaudojimo klausimai skatina ieškoti būdų, kaip prisitaikyti prie šių teritorijų dirvožemių dangos ypatumų. Čia dirvožemiai pasižymi mažu humusingumu (organinès anglies kiekiu), nepalankiu drègmès režimu ir kontrastinga dirvožemio danga. Tokių nenašių žemių savivaldybèse vykstantys intensyvesni žemès naudojimo pokyčiai leidžia planuoti didesnès apimties jų konversiją $\mathfrak{i}$ kitą nei buvo ūkinès veiklos kryptị ir / ar žemès naudojimo būdą (Abalikštienè, Aleknavičius, 2013).
Anglies akumuliacijos tyrimams skiriamas didelis dèmesys, tačiau dažniausiai vertinami suminiai ir įvairių anglies formų pokyčiai dirvožemyje. Skirtingai nei miškų žemėnaudose, per lauko sejomainų tyrimus biomasèje sukaupta anglis neretai lieka neịtraukta $\mathfrak{i}$ apskaitą ir pokyčiai neaptarti. Žemėnauda, sukaupianti didesnị anglies kiekị augalų biomasèje ir užtikrinanti augalų liekanų grąžinimą i dirvožemí, gali padidinti ir organinès medžiagos kiekio susidarymą jame (Saree et al., 2012; Liaudanskienè et al., 2013; Redin et al., 2014). Vis dèlto skirtingų žemėnaudų tyrimai smèlžemiuose, kur vyksta intensyvus organinès medžiagos skaidymas, neparodè statistiškai patikimų organinès 
anglies skirtumų visame armenyje, o tik atskiruose jo sluoksniuose (Armolaitis ir kt., 2013).

Iterptų í dirvožemị augalų biomasès destrukcijos procesus lemia daugelis veiksnių - biomasès kiekis, jos cheminè sudètis, hidroterminis režimas, mikrobiologinis aktyvumas ir įterpimo laikas (Marcinkonis et al., 2007; Arlauskienè ir kt., 2013). Tyrimai rodo, kad organinès medžiagos kieki dirvožemyje gali padidinti tik augalinès liekanos su nedideliu kiekiu azoto, o labiau azotingi nei 1,5\% augalai greičiau mineralizuojasi iki galutinių skilimo produktų (Kriaučiūnienè et al., 2012; Tripolskaja et al., 2014). Augalinių liekanų atsargos ir cheminè sudètis skirtinguose dirvožemiuose yra nevienodi, tačiau tai yra dirvožemio organinès medžiagos susidarymo šaltinis, nuo kurio priklauso dirvožemio derlingumas, tolesnis jo gebejjimas sudaryti palankias sąlygas naujiems augalams augti, užtikrinti biologini aktyvumą ir kokybę (Jankauskas et al., 2009).

Tinkamas žemès naudojimo būdas su tam tikrais auginamais augalais - vienas iš svarbiausių tikslų, skirtų išlaikyti ir atkurti dirvožemio ir jame augančių agrosistemų derlingumą. Tokiu būdu susidaro uždaras ciklas, kadangi augalų liekanų pagalba sukurtas dirvožemio derlingumas sukuria tam tikrą gebejjimą aprūpinti augalus maistingomis medžiagomis ir jų pasisavinimo potencialas gali būti keičiamas taikant skirtingus žemėnaudos būdus (Nemeikšienė ir kt., 2010; Powlson et al., 2011).

Antžeminė ir požeminè augalų biomasė, turinti skirtingą poveikị organinès anglies kaupimui dirvožemyje, labai skiriasi, nes humusinių medžiagų susidarymas priklauso nuo augalų rūšių, žemès naudojimo būdo bei kitų veiksnių (Marcinkonis et al., 2007; Redin et al., 2014). Ivairios žemėnaudos taip pat gali paskatinti ir dirvožemio organinès medžiagos kiekio spartų mažejimą, kuris vyksta dèl padidejjusios pasèlių likučių mineralizacijos, žemès dirbimo poveikio bei kitų naudojamų agropriemonių (Sabienè et al., 2010).

Norint padidinti organinių medžiagų kiekį lengvos granuliometrinès sudèties dirvožemyje, reikètų padidinti augalų sukaupiamą anglies kiekį ir sumažinti organinių medžiagų nuostolius (Cely et al., 2014; Whitman et al., 2014). Tai galima pasiekti keičiant žemès naudojimą ir pasirenkant tvarų lauko sejjomainų taikymą ar daugiamečių augalų auginimą (Acharya et al., 2012; Alonso et al., 2012; Luo et al., 2014).
Šio tyrimo tikslas - nustatyti, kaip paprastojo išplautžemio (Haplic Luvisol) priesmèliuose ìvairūs žemès naudojimo būdai lemia anglies susikaupimą augalų biomasèje. Tada bus galima parinkti tinkamiausią žemènaudą ir augalus siekiant daugiausia akumuliuoti anglies lengvos granuliometrinès sudèties dirvožemiuose auginamų augalų biomasèje.

\section{METODAI IR SALYGOS}

Tyrimo vieta ir jos detalès. Lauko tyrimų eksperimento aikštelès įrengtos $1995 \mathrm{~m}$. LAMMC Vokès filialo lauko bandymų plote, esančiame Vilniaus rajone, Didžiųjų Lygainių kaime (1 pav.). Eksperimento aikštelès yra Pietryčių Lietuvos dirvožemio zonoje, kurioje vyraujančių dirvožemių agronominè vertè dažnai yra labai maža, dirvožemio bazinis žemès našumas vertinamas <37 balų (Lietuvos žemès našumas, 2011). Geomorfologiniu aspektu tai fliuvioglacialinè sritis, kurios reljefas - silpnai banguota lyguma su nedideliu pažemèjimu i pietus.

Eksperimento aikštelès (4) įrengtos vidutinišskai sukultūrintame lauko sejomainos priesmèlio paprastajame išplautžemyje (Haplic Luvisol). Eksperimento schema apèmè ariamos žemès transformavimo ił mišką procesą su vidutinès (pievos bei dirvono) ir ilgalaikès (apželdinimo mišku) trukmès žemėnaudos kaitos variantais. Šio tyrimo irrengimas ir pirmųjų metų rezultatai plačiau aptarti M. Petrovo publikacijose (1999, 2000, 2001).

Aikštelèse taikytos šios žemėnaudos: 1) sèjomaininio lauko, kurioje auginti tradiciniai šiai zonai augalai (L) - grikiai (Fagopyrum esculentum), žieminiai rugiai (Secale cereale L.), vasariniai miežiai (Hordeum vulgare L. nutans), raudonieji dobilai (Trifolium pratense), bulvès (Solanum tuberosum), siauralapiai lubinai (Lupinus angustifolius L.); 2) kultūrinès pievos $(\mathrm{P})$ - augintas liucernos (Medicago varia L. 35-40 \%) ir miglinių žolių mišinys; 3) dirvono (D), kuriame per keletą metų susiformavo priesmèlio dirvožemiui būdinga natūrali fitocenozė; 4) apželdintos pušimis (M), kur augo paprastosios pušys (Pinus Sylvestris) (1 pav.). Lauko ir kultūrinès pievos aikštelès padalytos ị dvi dalis (1 pav.). Viena buvo netręšiama, kitoje naudotos mineralinès NPK trąšos, kurių norma buvo skaičiuojama pagal auginamų augalų mitybos elementų poreiki (Marcinkonis ir kt., 2014). 
Visos tyrimo aikštelès išdèstytos vienoje eilëje. Bendras kiekvienos eksperimento aikštelès plotas $-324 \mathrm{~m}^{2}(18 \times 18 \mathrm{~m})$ (1 pav.).

L aikštelejje nuo 1995 iki $2004 \mathrm{~m}$. buvo auginami įvairūs žemès ūkio augalai, kurių santykinę dalị per tyrimų laikotarpi sudarè: daugiametès žolès (20\%), kaupiamieji (30\%), migliniai javai (30\%) ir migliniai javai su daugiamečių žolių ịsèliu (20\%); 2005 m. L aikštelèje buvo paliktas pūdymas; nuo 2006 iki $2014 \mathrm{~m}$. buvo auginami aliejiniai (11\%), rūgtiniai (34\%), migliniai javai su daugiamečių žolių ìsèliu (11\%), daugiametès žolès (11\%), pupiniai (11\%) ir migliniai javai (22\%). Pasèlių sèjos ir priežiūros darbai buvo atliekami laikantis rekomenduojamų auginimo technologijų ir tręšiama atsižvelgiant ị maisto medžiagų atsargas dirvožemyje $\left(\mathrm{N}_{0-100} \mathrm{P}_{30-90} \mathrm{~K}_{30-120}\right)$. Naudotos amonio salietros, superfosfato bei kalio chlorido formų trąšos.

$\mathrm{P}$ aikštelëje buvo auginamas hibridinès liucernos (Medicago varia L. 35-40 \%) ir keturių varpinių žolių mišinys - raudonasis eraičinas (Festuca rubra) arba nendrinis eraičinas (Festuca arundinacea) - $20 \%$, beginklè dirsè (Bromus inermis) - $20 \%$, paprastoji šunažolè (Dactylis glomerata) arba pašarinis motiejukas (Phleum pratense) 10-15\% ir pieviné migle (Poa pratensis) $10 \%$. Per 12 m. laikotarpi žolynas paseno, todèl $2007 \mathrm{~m}$. buvo atsètas. $\mathrm{P}$ aikštelè taip pat buvo padalyta ị dvi dalis - tręšiamą ir netręšiamą. Trę̧šiamos dalies žolynas tręštas mineralinèmis trąšomis $\mathrm{N}_{60} \mathrm{P}_{90} \mathrm{~K}_{120}$, šienautas 2-3 kartus. Tręšta pavasarị vegetacijai atsinaujinus ir po pirmos pjūties.
$\mathrm{D}$ ir $\mathrm{M}$ aikštelèse nevykdomi jokie agrotechniniai darbai. Dirvone susiformavo natūralios augalijos fitocenozè, kurios sudètis variavo priklausomai nuo hidroterminių sąlygų vegetacijos metu. Pušimis apželdintoje aikštelëje 20 metų auga paprastosios pušys (Pinus Sylvestris), 2009 m. retinta - pušyno tankumas 4975 vnt. ha ${ }^{-1}$.

Ėminių ėmimas ir augalų biomasès anglies apskaičiavimas. Augalų èminiai iš L, P aikštelių imti kasmet augalų derliaus nuėmimo metu. D aikšteleje augalų biomasès apskaita daryta vieną kartą per vegetacijos laikotarpi augalų žydèjimo tarpsniu (birželio I dekada). Buvo nustatoma pagrindine ir šalutinè augalų produkcija bei šaknų biomasè. Bulvių gumbai apskaityti kaip pagrindinè produkcija, o nagrinejjant atskirai antžeminę ir šaknų biomasę buvo priskirti prie antžeminès (Bolinder ir kt., 2007). Sukauptas anglies kiekis augalų antžeminèje biomasèje ir šaknyse ịvertintas atsižvelgus ị literatūros duomenis apie vidutini jos kiekị augaluose (Alexeyev, Birdsey, 1998; Birdsey, 1998; IPCC Guidelines..., 2006). Remiantis šiais duomenimis, aikšteliu augalų biomasès anglis buvo apskaičiuota pagal lygtị:

$C=\mathrm{S} . \mathrm{M} . \times 0,5$

$C$ - anglies kiekis augalų biomaseje, $\mathrm{t} \mathrm{ha}^{-1}$;

S. M. - sausujų medžiagų kiekis augalų biomasèje, $\mathrm{t} \mathrm{ha}^{-1}$.

Sejomainos lauko ir dirvono sausųjų medžiagu kiekis augalų šaknyse apskaičiuotas iš $0-25 \mathrm{~cm}$ dirvožemio armens èminio, remiantis augalų antžeminès

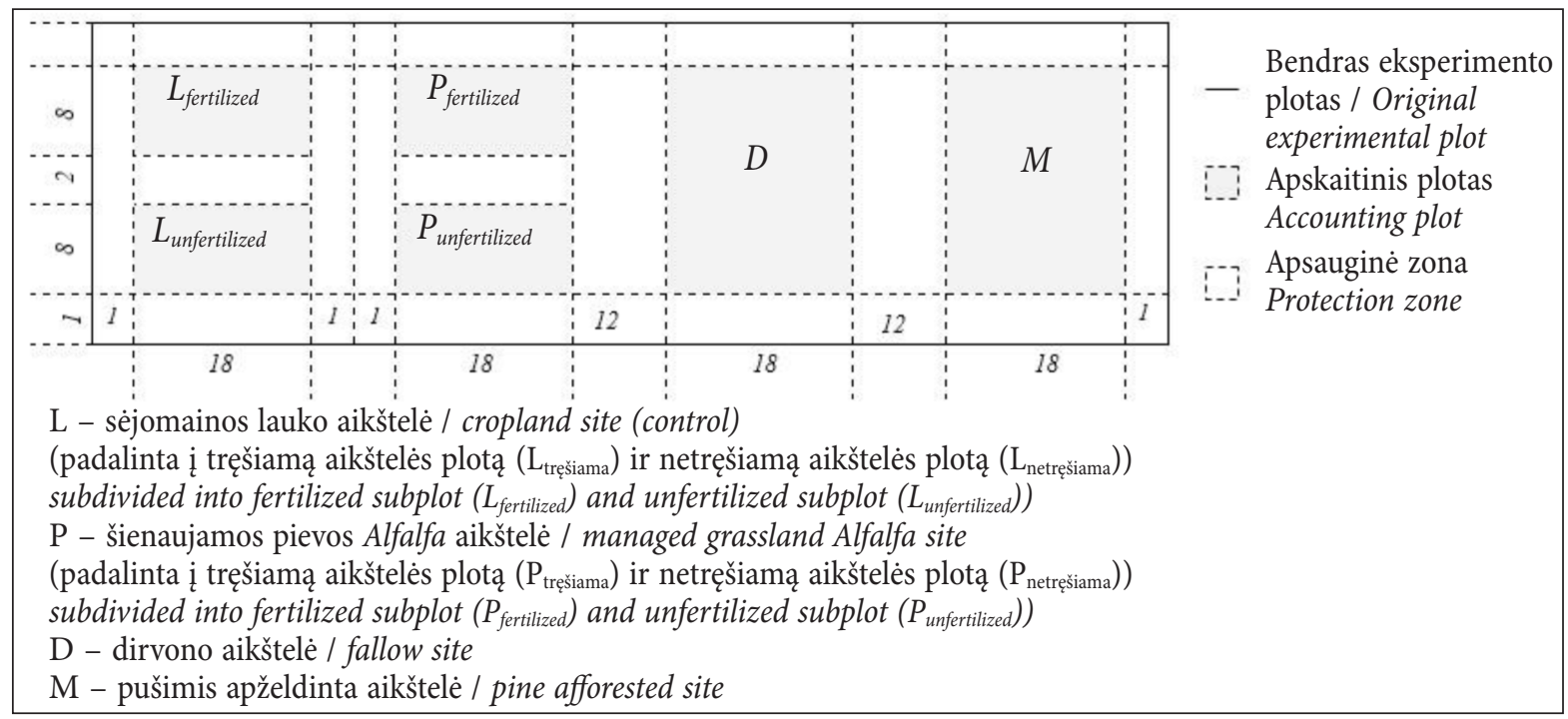

1 pav. Lauko eksperimento schema metrais

Fig. 1. Scheme of experimental field design, in meters 
produkcijos sausųjų medžiagų kiekiu ir atskiriems augalams pritaikius individualius koeficientus (Organines trąšos, 1992; Romanovskaja, 2003).

Šienaujamos pievos sausųjų medžiagu kiekis augalų šaknyse apskaičiuotas remiantis augalų antžeminés produkcijos sausųjų medžiagų kiekiu, pritaikius individualų koeficientą ir atsižvelgus ị trumpaamžių ir daugiamečių šaknų atsinaujinimą (Podzemnaya chast' travyanistykh..., 1986; Gill et al., 2002).

Pušų tūris nustatytas pagal medžiu skersmenị (1,30 m aukštyje), aukštị ir tankumą. Duomenys apdoroti ir pušies želdinių tūris apskaičiuotas LAMMC Miškų institute parengta programa. Želdinių šaknų tūris nustatytas remiantis antžeminès produkcijos tūriu pritaikant koeficientą (Xiao et al., 2003).

Statistiniams skaičiavimams naudoti statistinio duomenų apdorojimo paketai Minitab, Analysis ToolPak (iš MS Excel 2010). Atlikta koreliacinè analizè tarp ìvairių fitocenozių sukaupiamos antžeminès anglies ir vidutinių temperatūrų bei vidutinių kritulių kiekio per vegetacijos laikotarpi.

Meteorologinès sąlygos. Tyrimų metais (19952014) augalų vegetacijos laikotarpiu meteorologinès sąlygos buvo labai įvairios (2 pav.). Vidutinè oro temperatūra vegetacijos metu Trakų Vokeje sieké
$14,2{ }^{\circ} \mathrm{C}$ (variavo nuo 13,2 iki $15,5^{\circ} \mathrm{C}$ ), vidutinis kritulių kiekis - $411 \mathrm{~mm}$ (variavo nuo 235 iki $697 \mathrm{~mm}$ ).

Lietingais metais per vegetacijos periodą iškritusių kritulių kiekis viršijo kritulių vidurkị nuo 14 iki $70 \%$ 1998, 2005, 2010 ir 2011 metais. Per tyrimo laikotarpi $20 \%$ metų buvo labai lietingi, taip pat $20 \%$ metų buvo ir labai sausringi. Analogiška situacija ir su temperatūromis - per tyrimo laikotarpi $20 \%$ metų buvo labai karšti, ir vegetacijos laikotarpiu temperatūrų vidurkiai pasieke $15-15,5^{\circ} \mathrm{C}$. Aukštesni temperatūrų vidurkiai buvo 1999, 2002, 2010 ir 2011 metais. 2010 ir 2011 m. iškrito ne tik daug kritulių, tačiau ir temperatūrų vidurkis buvo 6-9 \% didesnis už viso laikotarpio vidurkị. 1996, 1997, 1998 ir 2004 m. nustatyti mažesni temperatūrų vidurkiai - nuo 13,2 iki $13,5^{\circ} \mathrm{C}$.

\section{TYRIMŲ REZULTATAI IR JŲ APTARIMAS}

Iš 20 metų laikotarpio augalų biomasès anglies vertinimo duomenų nustatyta, kad priesmèlio dirvožemyje tradicineje lauko sejomainoje per metus vidutiniškai sukaupiama $1,98 \mathrm{t} \mathrm{ha}^{-1}$ anglies, o skirtumas tarp lauko sejomainos tręštos ir netręštos dalių sudaro 1,57 karto arba $0,72 \mathrm{t} \mathrm{ha}^{-1}$ per metus (lentelè).

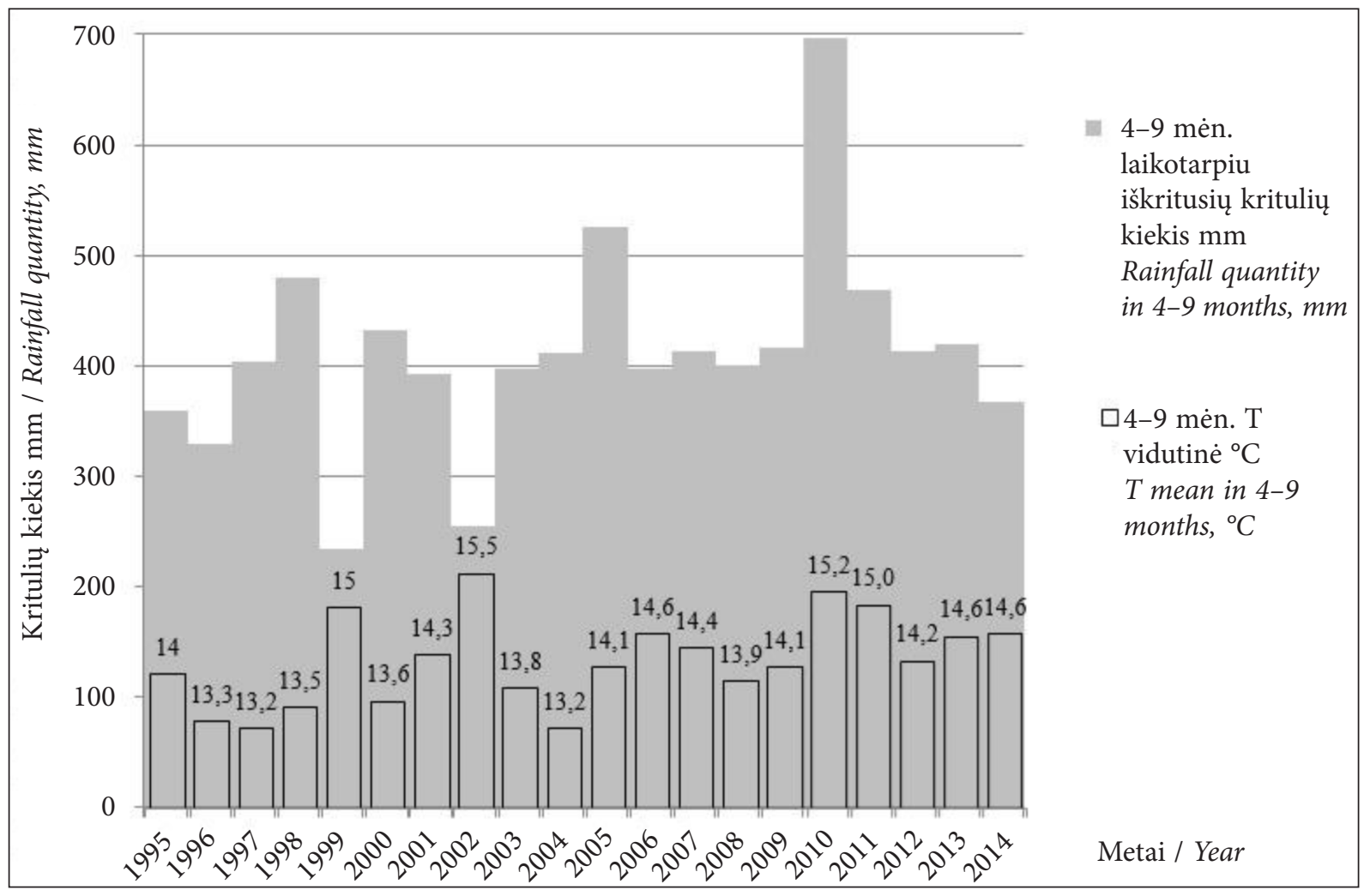

2 pav. Kritulių kiekis ir vidutinè temperatūra

Fig. 2. Rainfall quantity and average of temperature 
Lentelè. Antžeminėje biomasẻje ir šaknyse sukauptas vidutinis anglies kiekis ịvairiose fitocenozėse, 1995$2014 \mathrm{~m}$.

Table. Average of carbon stock accumulation in aboveground biomass and roots in different phytocenoses, 1995-2014

\begin{tabular}{|c|c|c|c|c|c|c|}
\hline \multirow{2}{*}{$\begin{array}{l}\text { Augalų biomasejje sukauptas } \\
\text { vidutinis anglies kiekis } \\
\text { Carbon stock average in plant biomass }\end{array}$} & \multicolumn{2}{|c|}{ Lauko sėjomaina / Cropland } & \multicolumn{2}{|c|}{ Pieva / Grassland } & \multirow{2}{*}{ 营 } & \multirow{2}{*}{ 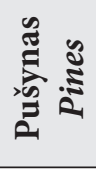 } \\
\hline & $\begin{array}{l}\text { tręšiama } \\
\text { fertilized }\end{array}$ & $\begin{array}{l}\text { netręšiama } \\
\text { unfertilized }\end{array}$ & $\begin{array}{l}\text { tręsiama } \\
\text { fertilized }\end{array}$ & $\begin{array}{l}\text { netrešiama } \\
\text { unfertilized }\end{array}$ & & \\
\hline $\begin{array}{l}\text { Antžeminè biomasè } \mathrm{tha}^{-1} \mathrm{~m}^{-1} \\
\text { Aboveground biomass, that } \mathrm{y}^{-1}\end{array}$ & 1,49 & 0,92 & 2,60 & 1,58 & 0,74 & 4,99 \\
\hline $\begin{array}{l}\text { Šaknys, tha-1 } \mathrm{m}^{-1} \\
\text { Roots, } t h a^{-1} y^{-1}\end{array}$ & 0,49 & 0,34 & 0,61 & 0,27 & 0,10 & 0,60 \\
\hline
\end{tabular}

Analizuojant atskirų metų lauko sėjomainos $\left(\mathrm{L}_{\text {trešsiama }}\right)$ augalų antžeminès biomasès anglies apskaitos rezultatus matyti akivaizdūs ìvairių augalų biomasejje akumuliuotos anglies skirtumai. Tie patys augalai pasižymèjo didele biomasẻje sukauptos anglies variacija atskirais metais: sausringais $2002 \mathrm{~m}$. tręštụ raudonųjų dobilų antžeminèje biomasèje buvo sukaupta tik 0,68 $\mathrm{t} \mathrm{ha}^{-1}$ anglies, $2009 \mathrm{~m}$. - 1,92 $\mathrm{t} \mathrm{ha}^{-1}$ ir $1998 \mathrm{~m}$. - net 3,24 $\mathrm{t} \mathrm{ha}^{-1}$ (3 pav.).
Gausiai antžeminèje biomasèje anglies sukaupdavo ne tik raudonieji dobilai, kurie vidutiniškai antžeminèje biomasèje akumuliavo $1,94 \mathrm{t} \mathrm{ha}^{-1}$, bet ir bulvès (įskaitant gumbus) - per metus vidutiniškai 2,72 t ha ${ }^{-1}$ (3, 4 pav.). Vasarinių rapsų (2006) ir siauralapių lubinų (2013) anglies kiekis augalus tręšiant buvo vienas mažiausių ir per metus sukaupdavo tik 0,61 ir 0,07 t ha ${ }^{-1}$ (3, 4 pav.). $2013 \mathrm{~m}$. siauralapių lubinų biomasejje akumuliuotos anglies

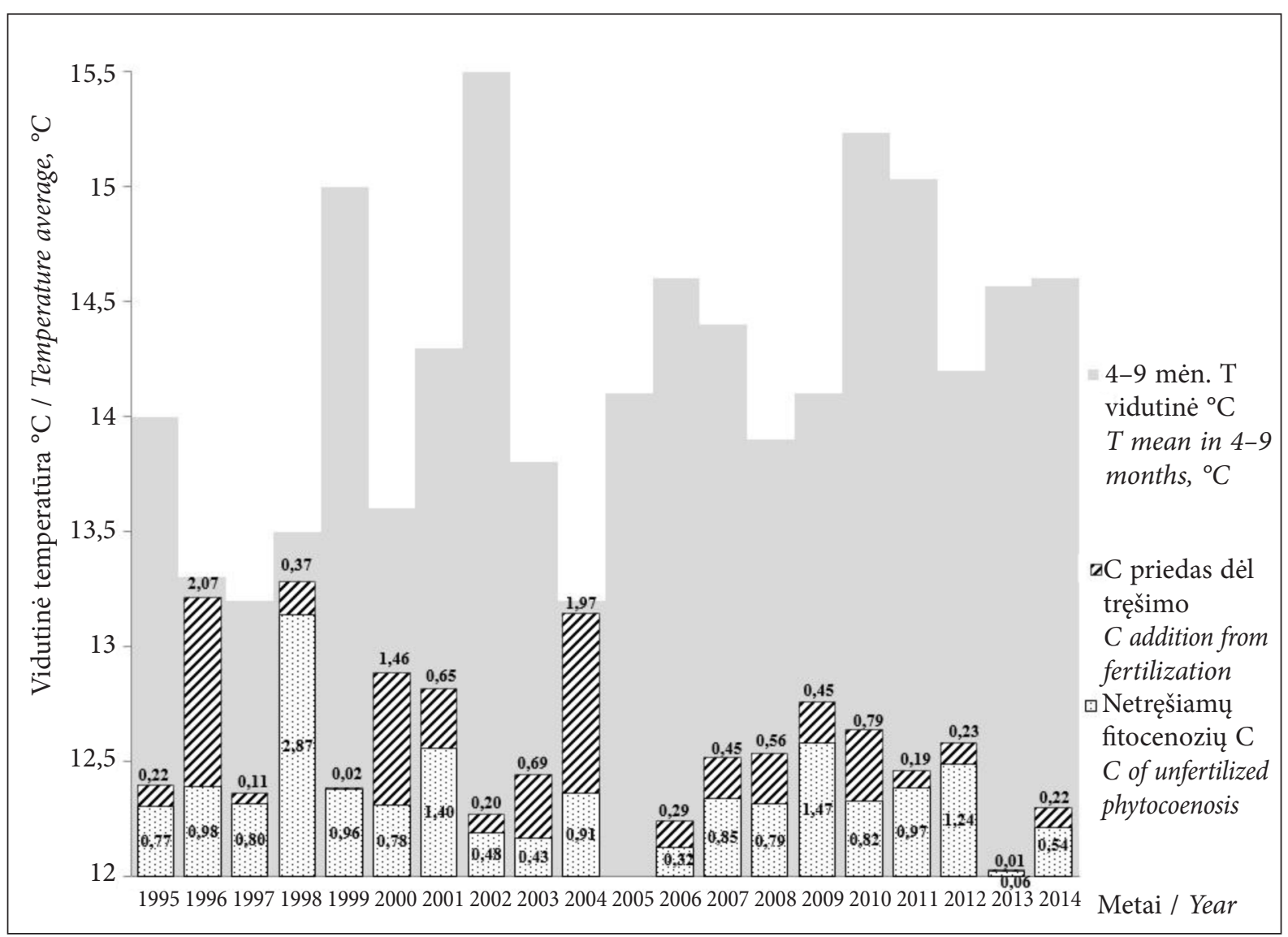

3 pav. Sejjomainos lauko ( $\mathrm{L}_{\text {tręšiama }}$ ir $\left.\mathrm{L}_{\text {netrę̌siama }}\right)$ antžeminès biomasès anglies kiekiai $\left(\mathrm{t} \mathrm{ha} \mathrm{h}^{-1}\right)$

Fig. 3. Stocks of cropland aboveground biomass carbon $\left(L_{\text {fertilized }}\right.$ and $\left.L_{\text {unfertilized }}\right)$, tha $a^{-1}$ 


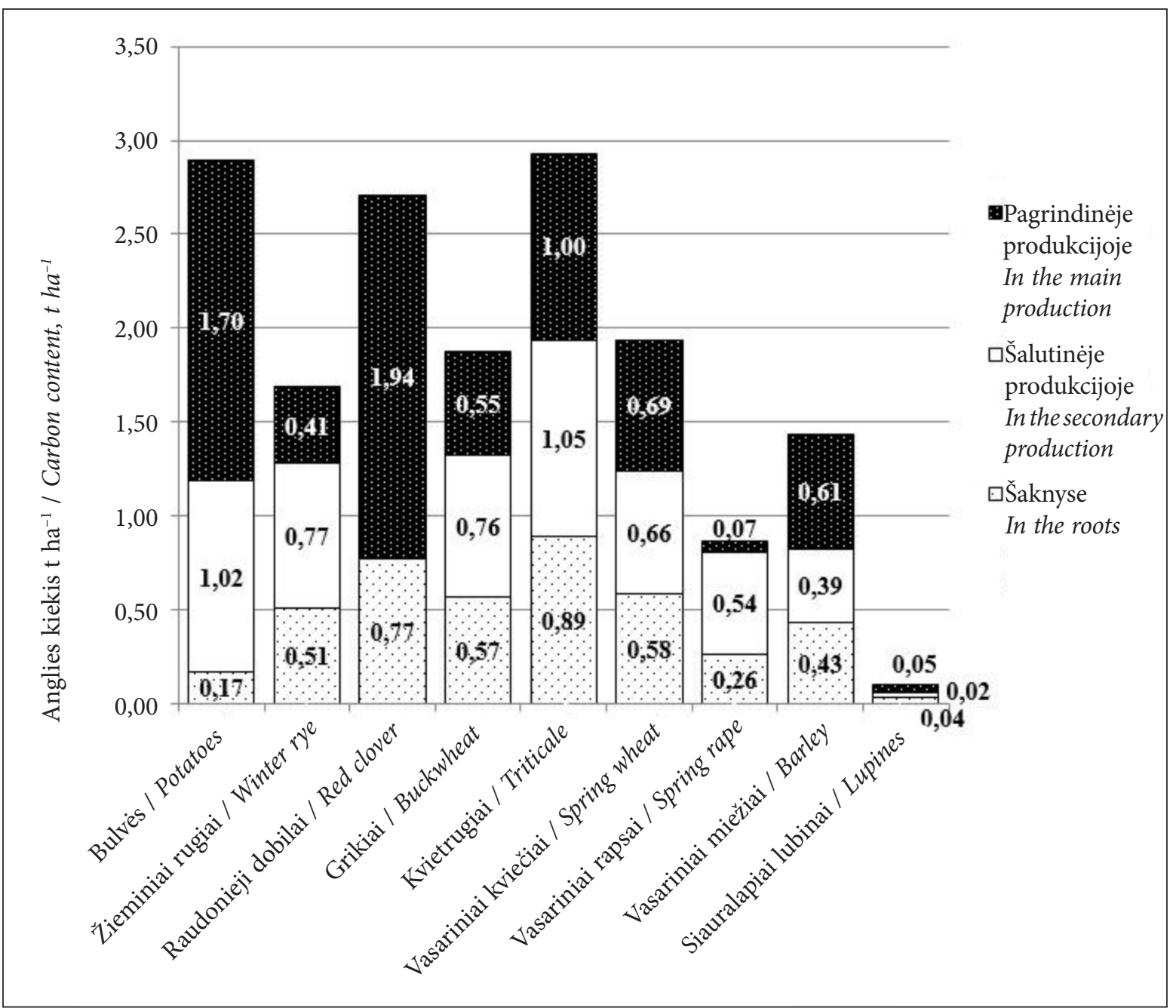

4 pav. Sėjomainos lauko $\left(\mathrm{L}_{\text {trẹšiama }}\right)$ vidutiniai augalų biomasės anglies kiekiai, 1995-2014 m.

Fig. 4. Average stocks of cropland plants biomass carbon $\left(L_{\text {fertilized }}\right), 1995-2014$

kiekis buvo labai mažas dèl lubinu pažeidimo antraktoze ir gauto labai mažo lubinų derliaus.

Sejomainoje $\left(\mathrm{L}_{\text {trę̧̇iama }}\right)$ auginant javus antžeminès biomasès anglies akumuliacija kvietrugių (2001) buvo 2,05 t ha ${ }^{-1}$, auginant vasarinius kviečius, grikius ir žieminius rugius antžeminès biomasès vidutiné anglies akumuliacija atitinkamai siekè 1,35, 1,31 ir 1,18 $\mathrm{t} \mathrm{ha}^{-1}$, o mažesnè akumuliacija vyko vasariniuose miežiuose - vidutiniškai $1,00 \mathrm{t} \mathrm{ha}^{-1}$ (3, 4 pav.).

Netręšto sejjomainos lauko antžeminès anglies akumuliacijos duomenys išryškina skirtingų biologinių augalų grupių gebëjimą produkuoti biomasę nederlinguose priesmèlio dirvožemiuose įvairiomis hidroterminèmis sąlygomis. Pavyzdžiui, vasarinių rapsų (2006) ir siauralapių lubinų (2013) antžeminès biomasès anglies kiekis buvo tik 0,32 ir $0,06 \mathrm{t} \mathrm{ha}^{-1}$, o 1998 m. raudonųjų dobilų - net 2,87 t ha-1 (3 pav.).
Netręšiamo lauko sẻjomainos antžeminejje biomasèje didesnis sukauptas vidutinis anglies kiekis buvo raudonųjų dobilų, kvietrugių, grikių ir bulvių (įskaitant gumbus), mažesnis - vasarinių kviečių, vasarinių miežių ir žieminių rugių, o mažiausias - vasarinių rapsų ir siauralapių lubinų (3 pav.).

Kitu autorių tyrimų rezultatai taip pat patvirtina didesnị raudonųų dobilų gaunamą derlių, kuriame sukaupiamas ir didesnis anglies kiekis raudonuju dobilų biomasèje, palyginti su kitų augalų biomase (Tripolskaja ir kt., 2012). Tyrimai su žieminiais rugiais ir miežiais rodo mažesnị sukauptą jų biomasès kiekį, taip pat ir mažesnę galimą anglies akumuliaciją. Pagal šalies mokslininkų tyrimų rezultatus, priesmèlio dirvožemyje bulvių, raudonųjų dobilų, miežių derlius atskirais metais gali skirtis apie 3 kartus (Tripolskaja, Šidlauskas, 2010; Asakavičiūtè, Ražukas, 2011). 
Tradicinès žemdirbystės antžeminių augalų biomaseje sukauptas anglies kiekis įvairuoja priklausomai nuo kasmet augintų augalų (3, 4 pav.). Nustatytas vidutinio stiprumo atvirkštinis ryšys $(r=-0,6)$ tarp tręšiamo sèjomainos lauko fitocenozių sukauptos antžeminès anglies ir augalų vegetacijos laikotarpio vidutinès temperatūros. Silpnas ryšys $(r=-0,4)$ buvo nustatytas tarp antžeminès anglies, sukauptos netręšiamose sejomainos lauko fitocenozèse, ir augalų vegetacijos laikotarpio vidutinès temperatūros. Išryškejjo neigiamas aukštesnių vegetacijos periodo temperatūrų poveikis augalininkystei. 1999 ir $2002 \mathrm{~m}$. vegetacijos periodas išsiskyrè sausesniu ir šiltesniu laikotarpiu, kai temperatūra viršijo $0,8-1,3^{\circ} \mathrm{C}$ vidutines temperatūras, o krituliu kiekis buvo $38-43 \%$ mažesnis už vidutinị kritulių kieki, vyko ir mažesnè anglies akumuliacija augaluose. Taip pat silpnas ryšys nustatytas ir tarp antžeminès anglies, sukauptos netręšiamose sëjomainos lauko fitocenozėse, ir augalų vegetacijos laikotarpio vidutinio kritulių kiekio, kurio tiesinès koreliacijos koeficientas su anglimi buvo $r=0,4$. Gauti duomenys patvirtina ir kitų mokslininkų (Kulikauskas, Sprainaitienè, 2005; Jundulas ir kt., 2009; Asakavičiūte, Ražukas, 2011) nustatytą priklausomybę tarp meteorologinių sąlygu bei gaunamo fitocenozių derliaus, kuris taip pat jame akumuliuoja ir didesni anglies kieki.

Gausiausia anglies, daugiau nei raudonųjų dobilų pasèlio šaknyse (vid. $0,77 \mathrm{t} \mathrm{ha}^{-1}$ per metus), buvo sukaupiama kvietrugių šaknų biomasejje $\left(0,89 \mathrm{t} \mathrm{ha}^{-1}\right.$ per metus), o mažiausia - lubinų šaknų biomaseje $\left(0,04 \mathrm{t} \mathrm{ha}^{-1}\right.$ per metus). Taip pat mažesni anglies kiekiai sukaupiami bulvių šaknų (vid. $0,17 \mathrm{t} \mathrm{ha}^{-1}$ per metus) ir vasarinių rapsu $\left(0,26 \mathrm{t} \mathrm{ha}^{-1}\right.$ per metus) šaknų biomasèje (4 pav.).

Keičiant žemènaudą iš ariamų žemių ị daugiamečių žolių fitocenozę (pievą), augalų produktyvumas ir atitinkamai anglies akumuliacija biomasejje padidejja. Per tyrimo laikotarpi tręšiamos pievos biomaseje vidutiniškai per metus sukaupta 3,21 t ha ${ }^{-1}$ anglies, netręšiant - vos $1,85 \mathrm{t} \mathrm{ha}^{-1}$ (lentelè). Skirtumas tarp tręštų ir netręštu pievos dalių sudaro 1,74 karto arba $1,36 \mathrm{t} \mathrm{ha}^{-1} \mathrm{~m}^{-1}$ (lentelè). Pažymètina, kad esant palankioms meteorologinèms sąlygoms tręšiamoje pievoje $1998 \mathrm{~m}$. fiksuotas didžiausias antžeminèje augalų biomaseje sukauptas anglies kiekis $-4,74 \mathrm{t} \mathrm{ha}^{-1}$, o tais pačiais metais anglies maksimumas sukauptas ir tręšiamoje lauko sejjomainoje auginant raudonuosius dobilus. Mažiausias tręšiamos pievos anglies kiekis buvo 2002 m. - 1,13 t ha ${ }^{-1}$, t. y. maždaug 4,2 karto mažesnis nei metais, kai buvo sukaupta daugiausia anglies (5 pav.).

Tais pačiais $2002 \mathrm{~m}$. mažiausias anglies kiekis antžeminèje biomasèje buvo akumuliuotas ir tręšiamos lauko sèjomainos raudonųjų dobilų biomasėje (3 pav.). Prastas derlingumas, taip pat ir mažas sukauptas anglies kiekis fitocenozèse buvo susijęs su labai sausu vegetacijos periodu ir aukštomis temperatūromis $2002 \mathrm{~m}$. augalų vegetacijos laikotarpiu. Vis dèlto, palyginti su lauko sejomainos fitocenoze, pievos fitocenozè sukaupe daugiau anglies antžeminèje dalyje.

Didžiausias netręštos pievos anglies kiekis antžeminèje dalyje per tyrimo laikotarpi taip pat buvo nustatytas $1998 \mathrm{~m}$. ir sudare $3,52 \mathrm{t} \mathrm{ha}^{-1}$, o mažiausias - $2009 \mathrm{~m}$., kuris akumuliavo $0,55 \mathrm{t} \mathrm{ha}^{-1}$ anglies (5 pav.), t. y. skirtumai siekè net 6,4 karto.

Viso laikotarpio duomenys rodo anglies kiekio akumuliacijos antžeminèje augalų biomaseje priklausomumą nuo meteorologinių sąlygų (5 pav.), taip pat nuo žolyno amžiaus. $1995 \mathrm{~m}$. pasejjus pievą 7 metus buvo stebimas anglies kiekio antžemineje dalyje didejimas, o po minèto 7 metų laikotarpio (nuo 2002) kasmetinis sukauptas anglies kiekis mažèjo, todèl 2006-2007 m. pieva buvo pakartotinai atsèta (5 pav.). Po pievos atsejjimo tręštos dalies antžeminèje biomasejje anglies buvo vèl sukaupiami didesni kiekiai, o netręštos dalies antžeminejje biomasejje, palyginti su tręštomis fitocenozèmis, šie kiekiai buvo mažesni (5 pav.).

Dalis mažo našumo dirvožemių paliekama dirvonuoti ir per tam tikrą laikotarpi paviršiuje susiformuoja natūralių augalų fitocenozè. Fitocenozejje palaipsniui mažèja sinantropinių rūšių reikšmè ir veikiamos natūralių aplinkos veiksnių atsiranda ir sustiprèja kitos rūšys, po pirmųjų metų mažèja fitomasès kiekis (Petrovas, 1999). Analizuojant 19952014 m. tyrimu duomenis nustatyta, kad dirvono sukauptas vidutinis anglies kiekis biomaseje buvo mažiausias $\left(0,85 \mathrm{t} \mathrm{ha}^{-1}\right.$ per metus) ir $48 \%$ mažesnis už netręšto lauko sèjomainos augalų biomasès vidutini anglies kiekį (1,26 tha ha per metus) (lentelè). Dirvono fitocenozė vidutiniškai per metus sukaupé $0,85 \mathrm{t} \mathrm{ha}^{-1}$ anglies, t. y. sistema daug mažiau gali sukaupti anglies kiekio, palyginti su tręštos pievos, tręšto sèjomainos lauko bei miško fitocenozėmis, kurių biomasejje vidutiniškai per metus sukaupe atitinkamai 3,21, 1,98 ir 5,59 $\mathrm{t} \mathrm{ha}^{-1}$ anglies. 


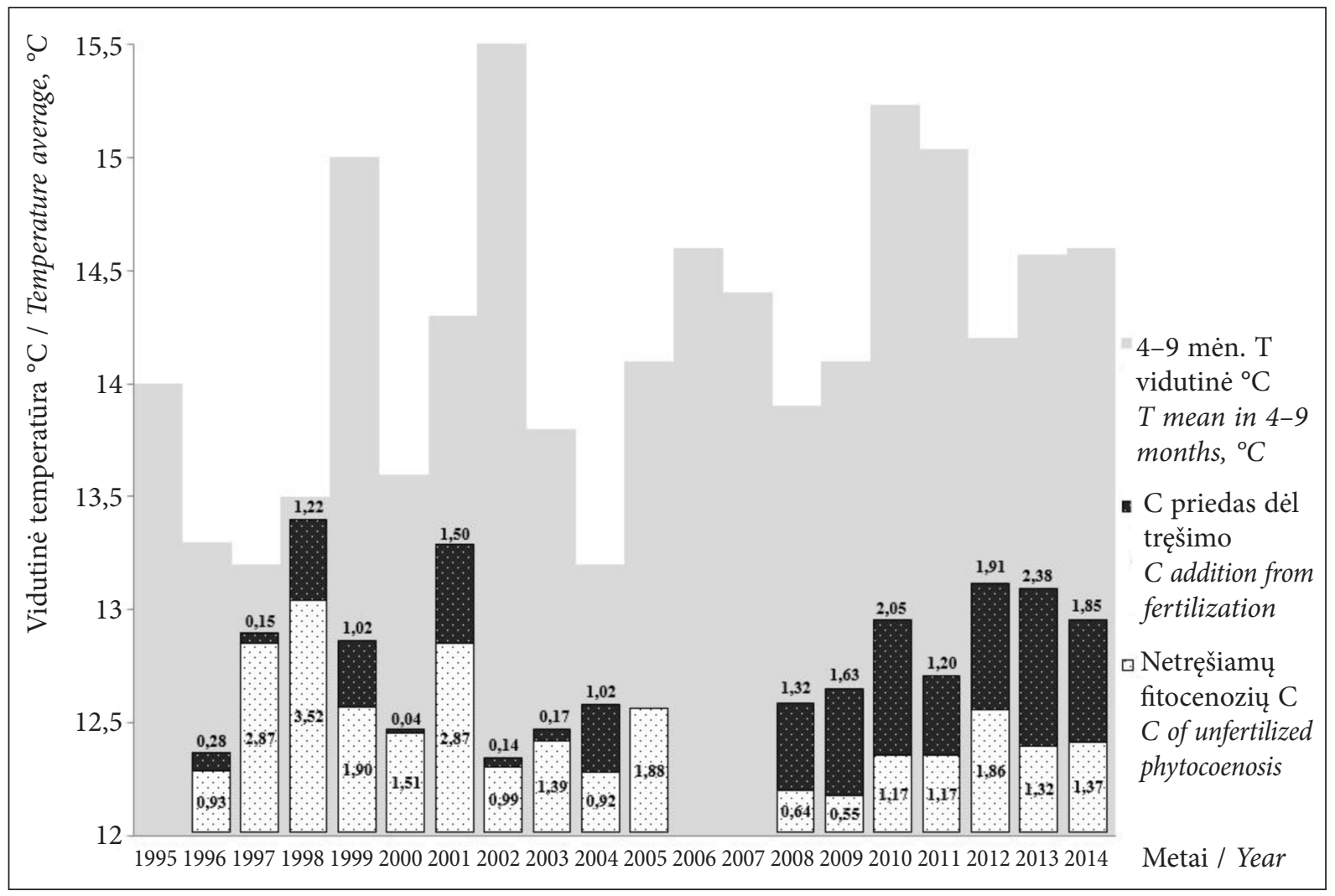

5 pav. Šienaujamos pievos $\left(\mathrm{P}_{\text {treșiama }}\right.$ ir $\left.\mathrm{P}_{\text {netrę̧iama }}\right)$ antžeminès biomasès anglies kiekis $t \mathrm{ha}^{-1}$

Fig. 5. Stocks of managed grassland aboveground biomass carbon $\left(P_{\text {fertilized }}\right.$ and $\left.P_{\text {unfertilized }}\right)$, tha ${ }^{-1}$

Mažiausia biomasès anglies susikaupè dirvono augalų antžeminèje dalyje 2012 m., t. y. tik $0,16 \mathrm{t} \mathrm{ha}^{-1}$ (6 pav.).

Pažymètina, kad $2002 \mathrm{~m}$. dirvono fitocenozès augalų biomaseje sukaupta net $1,11 \mathrm{t} \mathrm{ha}^{-1}$ (6 pav.). Toks anglies kiekis buvo tik šiek tiek mažesnis už tręštos pievos antžeminès biomasès anglies kieki $\left(1,13 \mathrm{t} \mathrm{ha}^{-1}\right)$ (5 pav.), joje akumuliuojant rekordiškai mažą anglies kiekí, siejamą su prastomis augalų vegetacijos laikotarpio meteorologinèmis sąlygomis. Žemei pradejus dirvonuoti, pastebima penkerių metų augalų biomasès anglies kiekio mažejimo tendencija, o tolesnis antžeminès augalų biomasès anglies kiekio kitimas skirtingais metais pasižymejjo didele variacija (6 pav.).

Išanalizavus visų eksperimento aikštelių anglies akumuliaciją antžeminèje augalų biomasèje per tyrimo laikotarpi, nustatyta, kad daugiausia vidutiniškai anglies sukaupe jauno pušyno fitocenozè $\left(4,99 \mathrm{t} \mathrm{ha}^{-1}\right.$ per metus), palyginti su tręšiamo sejjomainos lauko augalų biomase $\left(1,49 \mathrm{t} \mathrm{ha}^{-1}\right.$ per metus). Taip pat daugiau vidutiniškai anglies buvo akumuliuojama pušimis apželdintos aikštelès šaknyse $\left(0,60 \mathrm{t} \mathrm{ha}^{-1}\right.$ per metus), palyginti su sukauptu vidutiniu anglies kiekiu tręšiamo lauko augalų šaknyse $\left(0,49 \mathrm{t} \mathrm{ha}^{-1}\right.$ per metus) (lentelè).

$2013 \mathrm{~m}$. duomenimis, pušyno biomaseje sukaupta vidutinè anglis sudarè 5,59 $\mathrm{t} \mathrm{ha}^{-1}$. A. Balevičiūtè ir D. Veteikis (2012) nurodo, kad augalinès dangos kaitos, apaugimo mišku procesai greičiausiai vyksta būtent smèliuose ir priesmèliuose, šiek tiek lèčiau - priemoliuose, o lèčiausiai - durpių dirvožemiuose. Tyrimo rezultatai patvirtina per visą tyrimo laikotarpi miško fitocenozių biomasèje sukaupiamą didžiausią anglies kieki, palyginti su kitomis nagrinètomis fitocenozèmis.

Taip pat daugiau vidutiniškai anglies antžemineje augalų biomasèje sukaupe tręštos pievos (2,60 t ha ${ }^{-1}$ per metus), o mažiau - netręštos pievos fitocenozè (1,58 $\mathrm{t} \mathrm{ha}^{-1}$ per metus). Pievos šaknyse vidutiniškai buvo akumuliuojama daugiau anglies $\left(0,61 \mathrm{t} \mathrm{ha}^{-1}\right.$ per metus tręštos), palyginti su sukauptu vidutiniu anglies kiekiu tręštos sejomainos augalų šaknyse $\left(0,49 \mathrm{t} \mathrm{ha}^{-1}\right.$ per metus). Vidutiniškai per metus tręštos pievos biomasèje buvo sukaupta $3,21 \mathrm{tha}^{-1}$, o netręštos $-1,85 \mathrm{t} \mathrm{ha}^{-1}$ anglies (lentelè).

Tyrimais yra nustatyta, kad mažo našumo Rytų Lietuvos zonos dirvožemiuose (Vaičiulytė, 


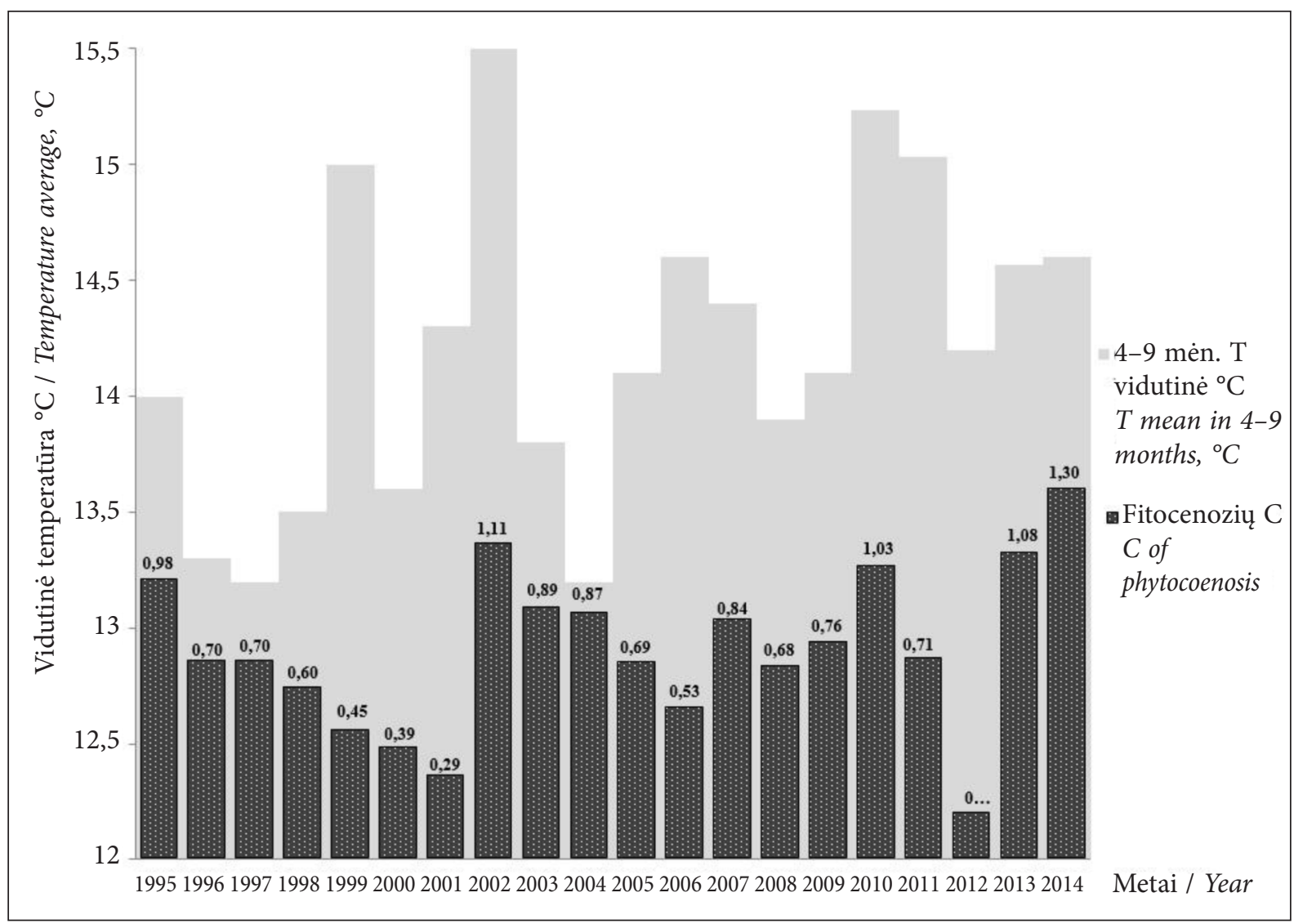

6 pav. Dirvono antžeminès biomasès anglies kiekis $\left(\mathrm{t} \mathrm{ha}^{-1}\right)$

Fig. 6. Stocks of fallow aboveground biomass carbon, $t$ ha ${ }^{-1}$

Bakšienè, 2011) bei kitos grupès ir klimatinių sąlygų dirvožemiuose (Nemeikšienė ir kt., 2010; Alonso et al., 2012) daugiametès žolès neblogai dera ir yra produktyvesnès už kitus augalus, taip pat akumuliuoja ir didesnius anglies kiekius fitocenozių biomaseje.

Sejomainos lauko fitocenozių antžeminèje biomasèje vidutinis sukauptas anglies kiekis $\left(1,49 \mathrm{t} \mathrm{ha}^{-1}\right.$ per metus tręštos ir $0,92 \mathrm{t} \mathrm{ha}^{-1}$ per metus netręštos) taip pat skyrèsi nuo dirvono fitocenozių vidutinès biomasès $\left(0,74 \mathrm{t} \mathrm{ha}^{-1}\right.$ per metus). Sèjomainos lauko augalų šaknyse vidutiniškai buvo akumuliuojama daugiau anglies $\left(0,49 \mathrm{t} \mathrm{ha}^{-1}\right.$ per metus), palyginti su sukauptu vidutiniu anglies kiekiu dirvono šaknyse $\left(0,11 \mathrm{t} \mathrm{ha}^{-1}\right.$ per metus $)$ (lentelè). Tyrimų duomenimis, dirvono augalų biomaseje sukaupta vidutinè anglis sudare tik $0,85 \mathrm{t} \mathrm{ha}^{-1}$ per metus, o tręšto sejomainos lauko $-1,98 \mathrm{t} \mathrm{ha}^{-1}$ ir netręšto $-1,26 \mathrm{t} \mathrm{ha}^{-1}$ (lentelè). Akivaizdu, kad nederlingose vietovèse nenaudinga vykdyti sèjomainą be trąšų ir palikti žemę dirvonuoti (lentelè). Mažą anglies kaupimą dirvono augalų biomasèje lemia mažesnis natūraliai augančiu augalų produktyvumas, kuris kultūrinès pievos augalų bendrijoms prilygsta tik itin nepalankių klimatinių sąlygų metais.

Atliktas skirtingų fitocenozių augalų biomasès anglies palyginimas yra tik vienas iš vertinimo kriterijų parenkant tinkamiausią žemėnaudą lengvos granuliometrinès sudèties dirvožemiuose.

\section{IŠVADOS}

1. Priesmèlio paprastajame išplautžemyje (Haplic Luvisol) tręšiamo lauko sejjomainoje gausiau antžeminejje augalu biomasëje anglies akumuliuodavo bulvès $\left(2,72 \mathrm{t} \mathrm{ha}^{-1}\right.$ per metus, isskaitant gumbus) ir raudonieji dobilai $\left(1,94 \mathrm{t} \mathrm{ha}^{-1}\right.$ per metus), mažiau - kvietrugiai $\left(2,05 \mathrm{t} \mathrm{ha}^{-1}\right.$ per metus), vasariniai kviečiai $\left(1,35 \mathrm{t} \mathrm{ha}^{-1}\right.$ per metus), grikiai (1,31 $\mathrm{tha}^{-1}$ per metus), žieminiai rugiai $\left(1,18 \mathrm{tha}^{-1}\right.$ per metus) ir vasariniai miežiai (1,00 t ha ${ }^{-1}$ per metus), o mažiausia - vasariniai rapsai $\left(0,61 \mathrm{t} \mathrm{ha}^{-1}\right.$ per metus) ir siauralapiai lubinai $\left(0,07 \mathrm{t} \mathrm{ha}^{-1}\right.$ per metus). 
2. Tręšimas mineralinèmis NPK trąšomis vidutiniškai 1,57-1,74 karto didino sukauptą anglies kieki daugiametèse žolèse ir lauko séjomainos augaluose.

3. Atskirais metais anglies akumuliacijos augalų biomasèje skirtumai tręšiamoje pievoje siekè 4,2 karto, o netręšiamoje - net 6,4 karto.

4. Sukauptas anglies kiekis tręšiamos lauko sèjomainos augalų antžeminèje biomasèje labiau priklausè nuo vegetacinio periodo oro temperatūros $(r=-0,6)$, nei netręšiamos lauko sejomainos fitocenozès $(r=-0,4)$, t. y. aukštesnès temperatūros mažino potencialiai fitocenozejje galimą sukaupti anglies kieki.

5. Vidutinių sukauptų anglies kiekių kitimo kryptis augalų biomasèje (fitomasèje) mažejančia linkme: pušimis apželdintos aikštelès $\left(5,59 \mathrm{t} \mathrm{ha}^{-1}\right.$ per metus $) \rightarrow$ tręštos pievos $\left(3,21 \mathrm{t} \mathrm{ha}^{-1}\right.$ per metus $) \rightarrow$ tręšto sejjomainos lauko $\left(1,98 \mathrm{t} \mathrm{ha}^{-1}\right.$ per metus $) \rightarrow$ netrešstos pievos $\left(1,85 \mathrm{t} \mathrm{ha}^{-1}\right.$ per metus) $\rightarrow$ netręšto sèjomainos lauko $\left(1,26 \mathrm{t} \mathrm{ha}^{-1}\right.$ per metus $) \rightarrow$ dirvono $\left(0,85 \mathrm{t} \mathrm{ha}^{-1}\right.$ per metus $)$.

6. Atliktas skirtingų fitocenozių biomasès anglies palyginimas yra svarbus kriterijus parenkant tinkamiausią žeménaudą lengvos granuliometrinès sudèties dirvožemiuose.

Gauta 20150610

Priimta 20150914

\section{LITERATŪRA}

1. Abalikštienė E., Aleknavičius P. 2013. Žemès ūkio paskirties žemès naudojimo tendencijos nenašių žemiu savivaldybèse. Žemès ūkio mokslai. T. 20(3). P. 159-169.

2. Acharya B. S., Rasmussen J., Eriksen J. 2012. Grassland carbon sequestration and emissions following cultivation in a mixed crop rotation. Agriculture, Ecosystems and Environment. Vol. 153. P. 33-39.

3. Alexeyev V. A., Birdsey R. A., eds. 1998. Carbon Storage in Forests and Peatlands of Russia. General Technical Report. NE-244. Radnor, U. S.: Department of Agriculture, Forest Service, Northeastern Forest Experiment Station. $137 \mathrm{p}$.

4. Alonso I., Weston K., Gregg R., Morecroft M. 2012. Carbon Storage by Habitat: Review of the Evidence of the Impacts of Management Decisions and Condition of Carbon Stores and Sources. Natural England Research Report NERR043. 44 p.

5. Arlauskiené A., Šlepetiené A., Nemeikšienè D. 2013. Pupinių žolių antžeminès masès, panaudotos žaliajai trąšai, poveikis anglies ir azoto poky- čiams glèjiškame rudžemyje (Gleyic Cambisol). Žemés ūkio mokslai. T. 20(4). P. 241-252.

6. Armolaitis K., Aleinikovienè J., Lubytė J., Žèkaitė V., Garbaravičius P. 2013. Stability of soil organic carbon in agro and forest ecosystems on Arenosol. Žemdirbysté-Agriculture. Vol. 100(3). P. 227-234.

7. Asakavičiūtė R., Ražukas A. 2011. Oro temperatūros bei atmosferos kritulių ịtaka bulvių derlingumui ir krakmolingumui Pietryčių Lietuvoje. Sodininkystè ir daržininkystè. T. 30(1). P. 61-70.

8. Balevičiūtè A., Veteikis D. 2012. Renatūralizacijos pokyčiai Lietuvos kraštovaizdyje 1995-2010 metais. Geografija. T. 48(2). P. 133-144.

9. Bolinder M. A., Janzen H. H., Gregorich E. G., Angers D. A., VandenBygaart A. J. 2007. An approach for estimating net primary productivity and annual carbon inputs to soil for common agricultural crops in Canada. Agriculture, Ecosystems and Environment. Vol. 118. P. 29-42.

10. Cely P., Tarquis A. M., Paz-Ferreiro J., Mendez A., Gasco G. 2014. Factors driving the carbon mineralization priming effect in sandy loam soil amended with different types of biochar. Soil Earth. Vol. 5. P. 585-594.

11. Gill R. A., Kelly R. H., Parton W. J., Day K. A., Jacksonc R. B., Morgan J. A., Scurlock J. M. O., Tieszen L. L., Castle J. V., Ojima D. S. Zhang X. S. 2002. Using simple environmental variables to estimate below-ground productivity in grasslands. Global Ecology \& Biogeography. Vol. 11. P. 79-86.

12. IPCC Guidelines for National Greenhouse Gas Inventories: Agriculture, Forestry and Other Land Use. 2006.

13. Jankauskas B., Jankauskienė G., Fullen M. A., Booth C. A., Šlepetiene A. 2009. Soil organic matter changes in Lithuanian soils: experiences and results. Žemdirbystè-Agriculture. Vol. 96(1). P. 85-97.

14. Jundulas J., Asakavičiūtė R., Ražukas A. 2009. Bulviu derlingumo priklausomybè nuo oro temperatūros bei atmosferos kritulių Pietryčiu Lietuvoje. Žemès ūkio mokslai. T. 16(1-2). P. 23-30.

15. Kriaučiūnienè Z., Velička R., Raudonius S. 2012. The influence of crop residues type on their decomposition rate in the soil: a litterbag study. Žemdirbysté-Agriculture. Vol. 99(3). P. 227-236.

16. Kulikauskas A., Sprainaitienè J. 2005. Avižų veisliu ir liniju derlingumo priklausomumas nuo oro temperatūros ir kritulių pasiskirstymo vegetacijos metu. Žemdirbystè: mokslo darbai. T. 89(1). P. 93-102.

17. Liaudanskienè I., Slepetiene A., Velykis A., Satkus A. 2013. Distribution of organic carbon in humic and granulodensimetric fractions of soil as influenced by tillage and crop rotation. Estonian Journal of Ecology. Vol. 62(1). P. 1-17. DOI: 10.3176/eco.2013.1.

18. Lietuvos žemès našumas: monografija. 2011. Sud. J. Mažvila. Akademija, Kèdainių r. 280 p. 
19. Luo Y., Zhao X., Andrén O., Zhu Y., Huang W. 2014. Artificial root exudates and soil organic carbon mineralization in a degraded sandy grassland in northern China. Journal of Arid Land. Vol. 6(4). P. 423-431.

20. Marcinkonis S., Pranaitis K., Lisova R. 2007. Studies on various buckwheat biomasses. Proceedings of 16th International Symposium of the International Scientific Centre of Fertilizers (CIEC), Mineral Versus Organic Fertilization: Conflict or Synergism. Ghent. P. 336-341.

21. Marcinkonis S., Kazlauskaitè-Jadzevičè A., Bakšienè E. 2014. Biogeniniu elementu ir energijos apytaka natūraliose ir kultivuojamose agroekosistemose: mokslinè ataskaita. LAMMC. 22 p.

22. Nemeikšienè D., Arlauskienè A., Maikštènienè S., Šlepetienė A. 2010. Anglies ir azoto sukaupimas skirtingų daugiamečių žolių biomasèje. LŽŪU mokslo darbai. T. 87(40). P. 41-50.

23. Organinès trąšos. 1992. Sud. E. Lukošiūnienè. Vilnius. $74 \mathrm{p}$.

24. Petrovas M. 1999. Lauko agrofitocenozių pradinès renatūralizacijos geobotaniniai tyrimai Pietryčių Lietuvos lengvų dirvožemių monitoringo programoje. Žemés ūkio mokslai. Nr. 3. P. 3-11.

25. Petrovas M. 2000. Apie nenašių Pietryčių Lietuvos dirvožemių konservavimo būtinybę ir perspektyvas. III-osios Respublikinès jaunuju mokslininku konferencijos „Lietuva be mokslo - Lietuva be ateities" pranešimu medžiaga. Vilniaus: Gedimino technikos universitetas. P. 206-213.

26. Petrov M. 2001. K voprosu o racional'nom ispol'zovanii malo-produktibnykh zemel' Litvy. Pochvy $i$ $i k h$ plodorodie na rubezhe stoletiy. Kn. 3. Aktual'nye problemy plodorodiya pochv $v$ sovremennykh ysloviyakh. Minsk. S. 117-120.

27. Podzemnaya chast' travyanistykh rasteniy i fitotsenozov v Litovskoy SSR. Sud. N. A. Lapinskienè. Vilnius. 1986. S. 11-17.

28. Powlson D. S., Gregory P. J., Whalley W. R., Quinton J. N., Hopkins D. W., Whitmore A. P., Hirsch P. R., Goulding K. W. T. 2011. Soil management in relation to sustainable agriculture and ecosystem services. Food Policy. Vol. 36(1). P. 7287.

29. Redin M., Guénon R., Recous S., Schmatz R., Liberalesso de Freitas L., Celso Aita, Sandro José
Giacomini. 2014. Carbon mineralization in soil of roots from twenty crop species, as affected by their chemical composition and botanical family. Plant Soil. Vol. 378(1-2). P. 205-214.

30. Romanovskaja D. 2003. Ivairiu organiniu trąšu poveikis dirvožemio agrocheminems savybems ir mineralinio azoto migracijai: daktaro disertacijos santrauka. 33 p.

31. Sabienė N., Kušlienė G., Zaleckas E. 2010. The influence of land use on soil organic carbon and nitrogen content and redox potential. ŽemdirbystéAgriculture. Vol. 97(3). P. 15-24.

32. Saree S., Ponphangnga P., Sarobol E., Limtong P., Chidthaisong A. 2012. Soil carbon sequestration affected by cropping changes from upland maize to flooded rice cultivation. Journal of Sustainable Energy \& Environment. Vol. 3. P. 147-152.

33. Tripolskaja L., Romanovkaja D., Šlepetienè A., Verbylienė I. 2012. Žaliosios trąšos ir mineralinių trąšų efektyvumo palyginimas žieminių rugių ir miežių derliui priesmèlio dirvožemyje. Žemès ùkio mokslai. T. 19(1). P. 27-35.

34. Tripolskaja L., Romanovskaja D., Slepetiene A., Razukas A., Sidlauskas G. 2014. Effect of the chemical composition of green manure crops on humus formation in a Soddy-Podzilicsoil. Eurasian Soil Science. Vol. 47(4). P. 310-318.

35. Tripolskaja L., Šidlauskas G. 2010. Tarpinių pasèlių žaliajai trąšai ir šiaudu itaka atmosferos kritulių filtracijai ir azoto išplovimui. ŽemdirbystéAgriculture. T. 97(1). P. 83-92.

36. Vaičiulytė R., Bakšienė E. 2011. Ekologiškų pievinių fitocenozių produktyvumas paprastajame išplautžemyje. Žemès ūkio mokslai. T. 18(3). P. 100108.

37. Whitman T., Zhu Z., Lehmann J. 2014. Carbon mineralizability determines interactive effects on mineralization of pyrogenic organic matter and soil organic carbon. Environmental Science \& Technology. Vol. 48(23). P. 13727-13734.

38. Xiao C. W., Yuste J. C., Janssens I. A., Roskams P., Nachtergale L., Carrara A., Sanchez B. Y., Ceulemans R. 2003. Above- and belowground biomass and net primary production in a 73-year-old Scots pine forest. Tree Physiology. Vol. 23(8). P. 505516. 
Asta Kazlauskaitè-Jadzevičè, Saulius Marcinkonis

ASSESSMENT OF PLANT BIOMASS CARBON STOCK IN DIFFERENTLY RENATURALIZED ARABLE LAND

\section{Sum $m$ ary}

Since 1995 investigations aiming to identify the influence of different renaturalization patterns on organic carbon accumulation in the biomass produced in phytocoenoses of sandy loam Haplic Luvisol soil in Lithuania are being performed at the Voke Branch of the Lithuanian Research Centre for Agriculture and Forestry (LRCAF). The summarized results of 20 years of research show that the highest average of carbon stock is accumulated in the biomass of forest plants (5.59 $\mathrm{t} \mathrm{ha}^{-1} \mathrm{y}^{-1}$ ), where Scots pine (Pinus sylvestris) grows, and the lowest average is in fallow land phytocoenoses $\left(0.85 \mathrm{t} \mathrm{ha}^{-1} \mathrm{~m}^{-1}\right)$. In the plant biomass of traditional cropland the average of carbon amount $\left(1.98 \mathrm{tha}^{-1} \mathrm{y}^{-1}\right)$ was a little bigger than the amount in phytocoenoses of unfertilized mowed meadows $\left(1.85 \mathrm{t} \mathrm{ha}^{-1} \mathrm{y}^{-1}\right)$. Fertilization with NPK fertilizers significantly (by 1.57-1.74 times) increased carbon accumulation in the crop rotation and meadow phytocoenoses. Aboveground carbon accumulation in phytocoenoses of fertilized crop rotation fields varies depending on crop types (from 0.07 till $3.24 \mathrm{tha}^{-1} \mathrm{y}^{-1}$ ). It was revealed that changeable hydrometeorological conditions during the vegetation season slightly or moderately influence the yield of crops, thus affecting aboveground carbon accumulation in the biomass produced by phytocoenoses. The correlation of the aboveground carbon accumulation amount in phytocoenoses of unfertilized cropland with air temperature was weak and negative $(r=-0.4)$, while with precipitation it was positive but also weak $(r=0.4)$. The analysis of the data revealed an inverse and moderate relationship $(r=-0.6)$ between the aboveground carbon accumulation in phytocoenoses of fertilized cropland and the average temperature of the vegetation period, i. e. higher temperatures reduce the potential amount of aboveground carbon accumulated in phytocoenoses.

Key words: biomass carbon stocks, renaturalization of arable land, Haplic Luvisol 